\title{
Research on the Construction of Sports Public Service Supply System Based on Diversified Model in China
}

\author{
Ze Zhang ${ }^{1, *}$ \\ ${ }^{1}$ Department of physical education of zhejiang international studies university, hangzhou zhejiang China 310023 \\ *Corresponding author. Email: 110173249@qq.com
}

\begin{abstract}
Sports public service is the sum of sports public products and service behaviors provided by public organizations to meet the sports needs of the people. Based on the analysis of the transformation and equalization measures of sports public service in developed countries, according to the public choice theory, new public management and new public service theory, aiming at solving government failure, market failure and voluntary failure, build a diversified sports public service system in China led by the government and introducing non-governmental organizations such as enterprises and social organizations.
\end{abstract}

Keywords: Sports Public Service, Supply, Diversification, China

\section{INTRODUCTION}

With the rapid development of China's economy and continuous social progress, The people's demand for equal distribution of social achievements is also increasing. The Party Central Committee and the State Council also clearly pointed out the requirements of adhering to the priority of people's livelihood, improving and ensuring the institutional arrangements for people's livelihood, promoting the equalization of basic public services, and establishing and improving the basic public service system ${ }^{[1]}$.The strategic deployment of the state to improve the public service system provides important opportunities and broad space for the development of sports in China ${ }^{[2]}$. However, Sports operation mechanism, organization mode, function setting, team quality and other aspects are facing very severe challenges ${ }^{[3]}$. At present, the construction of sports public service system needs to be continuously improved from the theoretical and practical levels. Through the introduction of competition mechanism, expand the purchase of services, realize the diversification of providers and modes of provision, and build a diversified supply system of sports public services in China.

\section{CONCEPT OF SPORTS PUBLIC SERVICE}

Internationally, it is considered that public service refers to the service provided to consumer groups with public needs or common preferences by relying on social public facilities or public departments and public resources $^{[4]}$. Samuelson believes that public goods are consumed for everyone and will not reduce the consumption of such goods by others. He points out that public goods are indivisible, non competitive and non exclusive $^{[5]}$. Based on the relevant theories and existing research of public service, combined with the characteristics of sports in China, this study believes that sports public service is the sum of sports public products and service behaviors provided by public organizations to meet the sports needs of the people.

\section{TRANSFORMATION AND EQUALIZATION MEASURES OF SPORTS PUBLIC SERVICES IN DEVELOPED COUNTRIES}

\subsection{Transformation of sports public services in developed countries}

\subsubsection{Promotion of government management reform}

As a social public welfare undertaking, sports is basically run by the government. The government is responsible for providing a large number of sports facilities, organizing large-scale sports events, developing youth sports, supervising professional sports events and other public sports services. Some developed 
countries have gradually realized that all sports public services are provided by the government, the diversified needs of the public can't be met. In order to change this situation, western developed countries implement socialized management of mass sports, delegate management power, and the private sector and non-profit sector undertake the responsibility of sports public service, so as to provide the public with the opportunity to participate in sports as much as possible ${ }^{[6]}$. In the socialization reform of sports public service, developed countries separate sports public service from the government and provide it by the market and non-profit organizations, which not only solves the problem of insufficient funds, but also improves the supply efficiency and promotes the rapid development of sports public service.

\subsubsection{Integration into the market economy system}

Developed countries transfer most of the management power of mass sports to society, encourage social institutions and individuals to participate in mass sports management, form a contractual relationship between public and private, and the government mainly intervenes in sports through legislation. The United States and Japan allocate special funds to invest in the construction of sports facilities to meet the basic physical exercise needs of citizens, and introduce a market-oriented operation mode to invest in the construction of sports facilities for social charges. In terms of professional sports, the governments of western countries basically do not interfere. Professional sports leagues manage themselves and allocate resources completely by the market, promote the success of professional sports commercialization reform in Europe and the United States ${ }^{[7]}$.

\subsubsection{Perfect facilities under welfare system}

"Welfare state" is the welfare system of western developed countries after World War II, which provides citizens with life security and infrastructure, and the public has the right to basically equal welfare treatment. In order to make up for the lack of public sports facilities, mass sports activities are mostly carried out by relying on the sports venues and facilities of various schools. On the whole, the coverage of basic sports facilities in developed countries is very high. In order to meet the needs of different levels, some market subjects are introduced, their management is relatively strict and their fees are low, which can better meet the diversified needs of the society [8].

\subsubsection{Participation of sports non-profit organizations}

Sports non-profit organizations in developed countries undertake most of the functions of sports public service and have made great contributions to the development of sports public service. In the early 19th century, England became the first region to develop sports clubs. a large number of sports associations have undertaken most of the sports public service functions for the government management reform, become the extension of the government organization functions ${ }^{[9]}$. Moreover, sports non-profit organizations in developed countries have strong independence in the supply of sports public services. In addition to providing certain financial assistance to non-profit organizations, the government basically does not interfere in management affairs. In addition, non-profit organizations such as sports clubs generally adopt the mass social organizations of membership system to provide sports public services for the society through the democratic management mode. Sports public services are not only subject to the internal supervision of sports associations, but also subject to the supervision of superior sports associations, members and government departments, so as to ensure the quality and efficiency in the supply of sports public services.

\subsection{Equalization measures in sports public services in developed countries}

\subsubsection{Ensure sports development in economically underdeveloped areas}

Regional economic differences exist in all countries. The equalization of sports public services at the regional level is the key level to realize the balanced development of sports public services. The United States, Canada, Japan and other countries started earlier in supporting the development of sports public services in economically backward areas, mainly by formulating policies and regulations to promote the balanced development of sports public services among regions ${ }^{[10]}$. Especially after the 1990s, developed countries basically take the balanced development of sports public services as the main goal of sports policy ${ }^{[11]}$. Through the formulation and implementation of policies and regulations, developed countries in the world support relatively backward areas, make the coordinated development of sports public services among regions, and promote the equalization of sports public services.

\subsubsection{Public sports services for key groups}

In the process of equalization of sports public services, many developed countries have strengthened the supply of sports public services for key groups, and promote the balanced development of social sports in their own countries. The Netherlands, Britain and Canada have launched sports public service policies for key groups, which not only improves the coverage of sports public services, but also promotes the equalization of sports public services. 


\section{THEORETICAL BASIS AND CONSTRUCTION OF DIVERSIFIED SUPPLY MODE OF SPORTS PUBLIC SERVICE IN CHINA}

\subsection{Theoretical basis for the construction of diversified supply mode of sports public services}

According to the public choice theory, the final trend of government providing public goods is obvious excess cost, namely "X-inefficiency"-because there is no competitor, the bureaucracy may over invest, produce more public goods than social needs, and even improperly expand institutions, increase employees, raise salaries and office expenses, resulting in a lot of waste. At the same time, there are defects in the supervision mechanism of government agencies and civil servants, resulting in neither market regulation nor effective institutional constraints on the provision of public goods ${ }^{[12]}$. Therefore, according to the public choice theory, the government monopolizes the supply of sports public services, resulting in bloated government institutions, low efficiency, failure to give full play to resources, and "government failure".

The new public management theory advocates redefining the role and function of the government, making full use of the power of the market and society, introducing market mechanism into public services, and adopting market management methods and experience to improve the efficiency of government public services. The government's function is to formulate public policies and supervise public service providers without directly providing public goods, which can reduce administrative costs, improve administrative efficiency, replace bureaucratic organizations with market model, introduce enterprise management technology into government management, introduce competition mechanism into government management, and adhere to customer orientation in public services ${ }^{[13]}$. Based on the new public management theory, the government departments in charge of sports should give full play to their advantages in formulating policies and regulations, and gradually turn from the sole provider of public goods to the policy makers who guarantee and realize sports public service products.

The new public service which criticizes and reflects on the entrepreneur government theory, holds that the interests of citizens should be put in the first place in public management. The primary task of the government is to serve and realize its interests for citizens, pay attention to civil society and citizenship, and pay attention to dialogue, communication and cooperative co governance between the government, the community and citizens ${ }^{[14]}$. According to the new public service theory, the sports public service system should not only introduce the government and market mechanism, but also give full play to the power of non-governmental organizations such as non-governmental organizations or social organizations to meet the interests and needs of the people.

\subsection{Theoretical enlightenment of the construction of diversified supply mode of sports public services in China}

\subsubsection{Government failure}

The unitary government supply system in China's sports public service is the product of the planned economic system. Under the command of the administrative orders of the state and the government, mobilize resources to support the construction of sports venues and facilities, in a relatively short time, it is China's public sports venues and facilities to form a certain scale. However, it also leads to overstaffing, large number of personnel and low work efficiency. With the improvement of people's income level and quality of life, the sports public goods provided by the government can't meet the diversification and differentiation of residents' consumption, which makes the resources not optimized and leads to "government failure".

\subsubsection{Market failure}

The "government failure" of sports public service products provides the possibility for the introduction of market mechanism. The government gives part of the power to provide sports public service products to the market. As the main body of the market, enterprises can adjust products by means of various market mechanisms. While making up for the lack of government regulation of sports public service products, marketization can't avoid the disadvantages of excessive marketization, which leads to the inequality of public sports services, the lack of fairness and efficiency of public sports services, and the "market failure" of sports public service products.

\subsubsection{Voluntary failure}

The existence of "government failure" and "market failure" of sports public service products makes it difficult to supply sports public service products effectively. The school of new public service theory believes that by introducing social forces such as nongovernmental organizations and using social mechanisms, it can make up for the failure of the government and society, provide the society with public goods that the first two can't provide, and meet the diversification of public needs. The government will transfer part of the functions of sports public service to non-governmental organizations to develop sports public service through social forces. The social supply of sports public service of various non-governmental organizations can not only share some functions of the government in providing 
sports public service and reduce the burden of government departments, but also make up for the phenomenon of "government failure" and "market failure" in the process of providing sports public service products. Therefore, the supply system of sports public service needs non-governmental organizations, the government and the market to cooperate to meet the different needs of the social public for sports public service.

\subsection{Construction of diversified supply model of sports public services in China}

The unitary government or market supply system of sports public service products cannot avoid the phenomenon of "government failure" or "market failure", while the socialized sports public service mechanism of non-governmental organizations can't avoid the emergence of "voluntary failure". Based on public choice theory, new public management theory and new public service theory, combined with the tendency of marketization and socialization of sports public service and the actual situation of the development of sports public service in China, this study believes that China's sports public service will establish a diversified supply model led by the government and introduced nongovernmental organizations such as enterprises and social organizations, Through the interaction and cooperation of government, enterprises and nongovernmental organizations in sports public service, we can maximize the needs of Chinese people at different levels of sports public service.

In the diversified supply mode of sports public service in China, the government is in the leading position, mainly includes government functional departments at all levels that provide sports public services to the public. Developing sports is the focus of our government's work and the responsibility of governments at all levels. With the basic establishment of China's market economic system, the government in the field of sports public service has gradually changed its role in standardizing the order of sports public service and ensuring the operation of sports public service market.

Enterprises play the role of producers, mainly include private fitness clubs or places for profit. With the basic establishment of China's market economic system, pure sports public service products have accounted for a minority, which exist in the form of quasi public products to a large extent, which makes it possible for enterprises adopting market mechanism to enter the field of public sports services. Enterprises can take various ways to participate in the construction of public sports facilities, or use the existing public sports facilities to provide paid sports services to consumers through contracting or principal-agent, and accept the guidance and support of the government in policies or regulations. Through paid sports services, enterprises adopting market mechanism mainly meet the differentiated needs of consumers for sports services, supplement the supply of public sports services, and improve the efficiency of resource supply. In addition, enterprises should give some support to nongovernmental organizations in terms of manpower, technology and even funds, promote non-governmental organizations to help improve the quality of sports public services and increase communication channels between enterprises and the public.

Non-governmental organizations act as a communication between sports public service consumers and producers, and promote the social equity of sports public service, mainly include individual sports associations, sports intermediary organizations, community sports clubs, charities or foundations and volunteer organizations. The sports public services provided by the government generally meet the needs of most people, but it is difficult to meet the needs of public services with great differences or special needs; Enterprises under the market-oriented mechanism aim at pursuing economic interests, which obviously cannot meet the basic needs of the public. Non governmental organizations that are not for profit and seek public interests can effectively mobilize some volunteers to make selfless contributions and attract social sponsorship and donations. The price of their public sports service products is very low and can meet the sports needs of ordinary people.

\section{CONCLUSION}

With the transformation of government functions in China, the concept of public service is gradually formed and established. As the leader in the supply system of sports public service, the government plays a role in ensuring the basic sports service needs of the general public. At the same time, through the participation of enterprises and non-governmental organizations, mobilize the three forces of government, market and society, meet the diversified and differentiated needs of sports public services, and promote the social equity of sports public services.

\section{REFERENCES}

[1]Xinhuanet. Outline of the 12th Five Year Plan for national economic and social development of the People's Republic of China [EB / OL]http://news.xinhuanet.com/politics/201103/16/c_121193916_3.htm,2011.

[2]People's daily. 12th Five Year Plan for sports development $\quad[\mathrm{EB}$ OL]http://sports.people.com.cn/GB/14300764.html ,2011.

[3]People's daily,Liu Peng: scientific planning, innovative development, promoting the construction 
of a sports power [EB / OL]http://sports.people.com.cn/GB/14300720.html ,2011.

[4]Liang Liu. Tracing and re understanding of the concept of sports public service in China [J]. Journal of physical education,2011, (3): 34-40.

[5]Yan Li. Course of public expenditure analysis [M]. Beijing: Peking University Press,2010:3.

[6]Hongjian Liu,Wenwen Gao, Qingzhu Sun. Theoretical basis and conceptual analysis of urban-rural integration of sports public service $[\mathrm{J}]$. Journal of sports adult education,2011, (1): 5-7.

[7] Jilan Tang. British public service reform and sports policy change [J]. Journal of Nanjing Institute of physical education,2010,24 (4): 43-47.

[8]Fengrong $\mathrm{Yu}$. My opinion on the socialization of public services in Canada [J]. Administrative forum,2008 (5): 86-88.

[9] Administrative Supervision Bureau of general affairs department. Current situation and problems of sports revitalization countermeasures [M].Tokyo: Printing Bureau of Tibet Province, 1990:33-35.

[10] Alam Bairner. Sport, Nationalism and Globalization: European and North American Perspectives[M] . New York: State University Press, 2001:95.

[11]Lifeng Gu, Liu Chang. On the rule of law in sports [M]. Chengdu: Sichuan Science and Technology Press, 2008:137.

[12]Guangyun Wu. On building an effective public service system with the interaction of government, market and civil society [J]. Jianghan forum, 2005, (9): 73 .

[13]Mingkun Chu, Lulu Yang. On the similarities and differences between new public service and new public management [J]. Zhongzhou journal, 2010, (4): 1 .

[14]manliang Zhu, Xuan Gao. From new public management to new public service: origin, debate and Enlightenment [J]. Journal of the Party School of the CPC Central Committee,2010, (4): 65. 